\begin{tabular}{llr} 
Revista Psicologia, Saúde \& Doenças & ISSN 2182-8407 \\
Vol. 22, No. 3, 1027-1035, 2021 & www.sp-ps.pt \\
DOÉnças & Sociedade Portuguesa de Psicologia da Saúde & https://doi.org/10.15309/21psd220321 \\
\hline
\end{tabular}

\title{
SELF-CONTROL, CONSUMPTION INDICATORS AND RISK FACTORS IN BRAZILIAN ADOLESCENTS
}

\section{AUTO CONTROLE, INDICADORES DE CONSUMO E FATORES DE RISCO EM ADOLESCENTES BRASILEIROS}

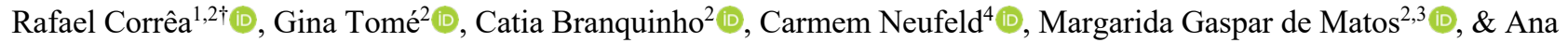 \\ Maria de Almeida $^{2}$ (D) \\ ${ }^{1}$ University of São Paulo, Ribeirão Preto School of Nursing, Ribeirão Preto, São Paulo, Brazil, rs.correa@usp.br, \\ amalmeid@eerp.usp.br \\ ${ }^{2}$ University of Lisbon, Faculty of Human Motricity, Lisbon, Lisbon, Portugal, ginatome@sapo.pt, catiasofiabranquinho@gmail.com, \\ mmatos@fmh.ulisboa.pt \\ ${ }^{3}$ University of Lisbon, Institute of Environmental Health, Lisbon, Lisbon, Portugal. \\ ${ }^{4}$ University of São Paulo, Faculty of Philosophy, Sciences and Letters of Ribeirão Preto, São Paulo, Brazil, cbneufeld@usp.br
}

\begin{abstract}
To analyze the association between self-control, consumption indicators and risk factors in the behavior of adolescents. Cross-sectional cohort study, with probabilistic sample by clusters and simple random. 722 teenagers were interviewed. The relationship of self-control with the use of tobacco, alcohol and cannabis, feeling of loneliness, sexual initiation, fights involvement was analyzed in the general group and stratified by gender. The Chi-square test and the Binomial Logistic Regression were used. In general, adolescents from the border region showed a high prevalence in the consumption of alcohol and tobacco, in contrast, they demonstrated a good repertoire of selfcontrol. Boys showed a relationship between reduced self-control with non-specific indicators of substance use, while girls showed a relationship between decreased self-control with alcohol and cannabis consumption. An association was identified between self-control, fight involvement, alcohol consumption and feeling of loneliness. The study presents important data for planning future research and interventions in Social Skills with adolescents in the border region based on the promotion of self-control for the prevention of substance use and risk factors.
\end{abstract}

Keywords: Adolescent; Social skills; Risk factors; Loneliness

Resumo: Analisar a associação entre auto-controle, indicadores de consumo e fatores de risco em adolescentes. Estudo de corte transversal, com amostra probabilística por conglomerados e aleatória simples. 722 adolescentes foram entrevistados. A relação de autocontrole com uso de tabaco, álcool e cannabis, sentimento de solidão, iniciação sexual e envolvimento em brigas foi analisada no grupo geral e estratificada por gênero. O Teste Chi-quadrado e a Regressão Logística Binomial foram usados. No geral os adolescentes de região de fronteira apresentaram alta prevalência no consumo de álcool e tabaco, em contrapartida demonstraram um bom repertório de auto-controle. Os meninos apresentaram uma relação entre a redução de auto-controle com indicadores não específicos do consumo de substâncias, enquanto as meninas, demonstraram uma relação entre a diminuição de autocontrole com o consumo de álcool e cannabis. Foi identificada uma associação entre auto-controle, envolvimento em brigas, consumo de álcool e sentimento de solidão. $\mathrm{O}$ estudo apresenta dados

\footnotetext{
†Morada de Correspondência: Aventura Social - Faculty of Human Motricity, University of Lisbon, Estrada da Costa, 1499-002, Cruz Quebrada, Portugal. Email: rs.correa@usp.br

Submetido: 19 de maio de 2021
}

Aceite: 11 de outubro de 2021 
importantes para o planejamento de futuras pesquisas e intervenções em Habilidades Sociais com adolescentes na região de fronteira baseada na promoção do auto-controle para a prevenção do consumo de substâncias e fatores de risco.

Palavras-Chave: Adolescente; Habilidades sociais; Fatores de risco; Solidão

Studies on consumption indicators show high prevalence and association with other risk factors in the adolescents health behaviours (Coutinho et al., 2016; Hallal et al., 2017; Horta et al., 2018). The relationship between substances use has been identified with other risk behaviours such as loneliness and fight involvement (Kim et al., 2018; Malta et al., 2018). Substance use in conjunction with risk behaviors such as exposure to violence in the border region in general has been characterized as a public health problem, and this region presents an atypical scenario with economic and social challenges increasing the possibility of involvement of adolescents in exploitation systems, increasing the risk to health vulnerability (Priotto, 2019).

Self-control is defined as an ability to demonstrate balance in situations that can cause discomfort, frustration, humiliation or anger (Del Prette \& Del Prette, 2009). Despite the recognition that selfcontrol has a positive influence on adolescent consumption indicators, the relationship with other risk factors is still an issue to be explored due to the variety of factors and possibilities of interventions (de Winter et al., 2016). Another important point to be considered in this relationship, would be the definition of priorities in conducting research and intervention studies, an issue that can be mitigated by the results of surveys on adolescent health on a national and international level (Brasil, 2016; Matos \& Equipa Aventura Social, 2018; WHO, 2016).

However, the importance of identifying priorities at local and regional level for consumption indicators and other risk factors of interest for future interventions is highlighted (Dos Reis et al., 2018). Thus, the study's hypothesis was that the high frequency of consumption indicators and risk factors in adolescent behaviour would be associated with low self-control among adolescents. Therefore, the objective of this study is to analyze the associations between self-control, consumption indicators and risk factors in the behaviour of adolescents.

\section{METHODS}

Cross-sectional study developed with adolescents from public schools in Foz do Iguaçu, Brazil. The region is bordered by Paraguay and Argentina and presents an atypical characterization in relation to the labor market, socio-economic, favoring the involvement and adolescents in the cycle of risky behaviors such as informal work, trafficking in goods and substances and prostitution (Aguiar, 2012). It was preceded by the consent of the institutions and participants as well as their legal guardians, respecting voluntary and anonymous participation. This research was approved by the research ethics committee of the Ribeirão Preto School of Nursing - University of São Paulo. This study was developed in accordance with the Declaration of Helsinki.

For data collection, an instrument validated by the National School Health Survey, authorized by the Brazilian Institute of Geography and Statistics (Brasil, 2016). A population-based survey was conducted with students from public schools in Brazil. This study is developed since 2009 and the instrument is structured with questions that include socio-demographic, risk and protective factors on adolescents' health (Oliveira et al., 2017).

There was also used the Social Skills Inventory for Adolescents (Del Prette \& Del Prette, 2009), which evaluates the social skills repertoire of adolescents, presented on a five-point Likert scale for frequency and difficulty. The values filled up by the respondents are converted into percentiles and later the scores for empathy, self-control, civility, assertiveness, affective approach, social 
resourcefulness and total are calculated as specified in the manual (Del Prette\& Del Prette, 2009). In this study was used self-control indicator for frequency and difficulty, which has internal consistency index of .72 and .75 respectively.

\section{Participants}

The final sample considered from refusals and dropouts was 722 adolescents. The average age of the adolescents was 16.5 years $(S D=0.80)$, being distributed between 1 st year $(M=15.6 ; \mathrm{SD}=0.78)$, 2nd year $(M=16.1 ; \mathrm{SD}=0.63)$ and $3 \operatorname{rd}$ year $(M=16.9$; $\mathrm{SD}=0.33)$ of high school and technician from public schools in Foz do Iguaçu.

\section{Measures and Variables}

This study includes variables of socio-demographic characterization, alcohol use and consumption, binge drinking, tobacco use, cannabis use, feeling of loneliness, sexual initiation and fight involvement. Self-control was calculated using the frequency indicator, which initially presented 5 levels of classification and was subsequently recoded into 2 levels, High (Highly elaborated, Elaborated and Good) and Low (Lower medium, Below lower average). And the difficulty indicator that was recoded in Low and High (Medium / High difficulty). The measures are shown in Table 1.

Table 1. Description of the variables involved in the study.

\begin{tabular}{|c|c|c|c|}
\hline Study variables & & Range & \\
\hline Age (years old)* & Minimum $=15$ & Maximum $=17$ & \\
\hline Gender & $1=$ Boy & $2=$ Girl & \\
\hline School grade (high school)* & $1=1^{\mathrm{st}}$ & $2=2^{\text {nd }}$ & $3=3^{\text {rd }}$ \\
\hline Alcohol use (in life) & $1=$ Yes; & $2=\mathrm{No}$ & \\
\hline $\begin{array}{l}\text { Alcohol consumption } \\
\text { (last month) }\end{array}$ & $\begin{array}{l}1=\text { None } ;=1-2 \text { times; } \\
3=3-5 \text { times; }\end{array}$ & $\begin{array}{l}4=6-9 \text { times; } 5=10-19 \\
\text { times; }\end{array}$ & $\begin{array}{l}6=20-29 \text { times; } 7=\text { Every } \\
\text { day }\end{array}$ \\
\hline Binge drinking (in life) & $1=$ None $; 2=1-2$ times; & $\begin{array}{l}3=3-5 \text { times; } 4=6-9 \\
\text { times; }\end{array}$ & $5=10$ times or more; \\
\hline Tobacco use (in life) & $1=$ Yes; & $2=\mathrm{No}$ & \\
\hline $\begin{array}{l}\text { Cannabis consumption } \\
\text { (last month) }\end{array}$ & $1=$ None; $2=1-2$ times; & $3=3-9$ times & $4=10$ times or more; \\
\hline $\begin{array}{l}\text { Feeling of loneliness (last } \\
\text { year) }\end{array}$ & $1=$ Never; $2=$ Rarely; & $\begin{array}{l}3=\text { Sometimes; } \\
4=\text { Frequently; }\end{array}$ & $5=$ Always \\
\hline Sexual initiation & $1=$ Yes; & $2=\mathrm{No}$ & \\
\hline Fight Involvement (last year) & $\begin{array}{l}1=\text { Never; } 2=\text { Once; } \\
3=2-3 \text { times; }\end{array}$ & $\begin{array}{l}1=\text { Never } 2=\text { Once; } \\
3=2-3 \text { times; }\end{array}$ & $\begin{array}{l}1=\text { Never; } 2=\text { Once; } \\
3=2-3 \text { times; }\end{array}$ \\
\hline Self-control - Frequency* & $\begin{array}{l}1=\text { Below average; } \\
2=\text { Lower average; }\end{array}$ & $\begin{array}{l}3=\text { Good } \\
4=\text { Elaborate }\end{array}$ & $5=$ Highly elaborate \\
\hline Self-control - Dificulty* & 1= Low difficulty; & $2=$ Average difficulty; & $3=$ High difficulty \\
\hline
\end{tabular}

Note: *This variables was recoded.

\section{Statistical data analysis}

The statistical analysis was performed through the descriptive test for all variables. Chi-square test was used to analyze the relationship between the indicators of substance use, risk factors and selfcontrol. Binomial Logistic Regression was used, using the "ENTER" method to analyze the influence 
of independent variables on self-control. The SPSS version 24 program was used for statistical analysis. The level of significance was $p<0.05$.

\section{RESULTS}

In general, adolescents had a higher prevalence in the indicators of alcohol use, $74 \%(\mathrm{n}=534)$, alcohol consumption, $42.8 \%(n=309)$, binge drinking, 39.6\% $(n=286)$ and tobacco use, 33.5\% $(n$ $=242$ ) compared to the national average (Brazil, 2016). The adolescents showed a high frequency, $70.4 \%(n=508)$ and difficulty, $64.4 \%(n=465)$ in self-control.

Table 2. Participants' characteristics. Foz do Iguaçu, Brazil, 2021.

\begin{tabular}{|c|c|c|c|c|}
\hline Variables & Total & Boys & Girls & \\
\hline & $\%(n)$ & $\%(n)$ & $\%(n)$ & $P$ \\
\hline & $100(722)$ & $100(328)$ & $100(394)$ & \\
\hline \multicolumn{5}{|l|}{ Age (years) } \\
\hline 15 & $29.8(215)$ & $26.2(85)$ & $32.7(129)$ & \multirow{3}{*}{$0.003 *$} \\
\hline 16 & $35.9(259)$ & $32.9(108)$ & $38.3(151)$ & \\
\hline 17 & $34.3(248)$ & $40.9(135)$ & $28.9(114)$ & \\
\hline \multicolumn{5}{|l|}{ School grade (high school) } \\
\hline $1^{\text {st }}$ & $42.2(305)$ & $43.3(142)$ & $41.4(163)$ & \multirow{3}{*}{0.870} \\
\hline $2^{\text {nd }}$ & $38.4(277)$ & $37.8(124)$ & $38.8(153)$ & \\
\hline $3^{\text {rd }}$ & $19.4(140)$ & $18.9(62)$ & $19.8(78)$ & \\
\hline \multicolumn{5}{|l|}{ Alcohol use (in life) } \\
\hline Yes & $74(534)$ & $72.6(238)$ & $75.1(296)$ & \multirow[t]{2}{*}{0.434} \\
\hline No & $26(188)$ & $27.4(90)$ & $24.9(98)$ & \\
\hline \multicolumn{5}{|c|}{ Alcohol consumption (last month) } \\
\hline Yes & $42.8(309)$ & $45.4(149)$ & $40.6(160)$ & \multirow[t]{2}{*}{0.193} \\
\hline No & $57.2(413)$ & $54.6(179)$ & $59.4(234)$ & \\
\hline \multicolumn{5}{|l|}{ Binge drinking (in life) } \\
\hline Yes & $39.6(286)$ & $39.9(131)$ & $39.2(155)$ & \multirow[t]{2}{*}{0.870} \\
\hline No & $60.4(436)$ & $60.1(197)$ & $60.7(239)$ & \\
\hline \multicolumn{5}{|l|}{ Tobacco use (in life) } \\
\hline Yes & $33.5(242)$ & $34.5(113)$ & $32.7(129)$ & \multirow[t]{2}{*}{0.628} \\
\hline No & $66.5(480)$ & $65.5(215)$ & $67.3(265)$ & \\
\hline \multicolumn{5}{|c|}{ Cannabis consumption (last month) } \\
\hline Yes & $5.3(38)$ & $7.6(25)$ & $3.3(13)$ & \multirow[t]{2}{*}{$0.010^{*}$} \\
\hline No & $94.7(684)$ & $92.4(303)$ & $96.7(381)$ & \\
\hline \multicolumn{5}{|c|}{ Feeling loneliness (last year) } \\
\hline Never/ Rarely & $75.8(547)$ & $80.2(263)$ & $72.1(284)$ & \multirow[t]{2}{*}{$0.011 *$} \\
\hline Always & $24.2(175)$ & $19.8(65)$ & $27.9(110)$ & \\
\hline \multicolumn{5}{|l|}{ Sexual initiation } \\
\hline Yes & $49.7(359)$ & $54.3(178)$ & $45.9(181)$ & \multirow[t]{2}{*}{$0.026^{*}$} \\
\hline No & $50.3(363)$ & $45.7(150)$ & $54.1(213)$ & \\
\hline \multicolumn{5}{|c|}{ Fight Involvement (last year) } \\
\hline Yes & $14.3(103)$ & $21.3(70)$ & $8.4(33)$ & \multirow[t]{2}{*}{$<0.001 *$} \\
\hline No & 85.7 (619) & $78.7(258)$ & $91.6(361)$ & \\
\hline \multicolumn{5}{|l|}{ Self-control - Frequency } \\
\hline Low & $39.9(282)$ & $35.4(116)$ & $42.1(166)$ & \multirow[t]{2}{*}{0.064} \\
\hline High & $60.1(440)$ & $64.6(212)$ & $57.9(228)$ & \\
\hline \multicolumn{5}{|l|}{ Self-control - Difficulty } \\
\hline Low & $35.6(257)$ & 42.4 (139) & $32.2(127)$ & \multirow[t]{2}{*}{$0.005^{*}$} \\
\hline High & $64.4(465)$ & $57.6(189)$ & $67.8(267)$ & \\
\hline
\end{tabular}

Note: ${ }^{*} p<0.05$ 
The boys showed higher alcohol consumption, $45.4 \%(n=149)$, tobacco use, $34.5 \%(n=113)$, cannabis use, 7.6\% $(n=25)$, sexual initiation, $54,3 \%(n=178)$ and fights involvement, $21.3 \%(n=$ $70)$ than girls. Girls reported greater use of alcohol, $75.1 \%(n=296)$ and greater feeling of loneliness, $27.9 \%(n=110)$ than boys. The binge drinking had a similar percentage for both genders, $39.9 \%(n$ $=131)$ for boys and $39.2 \%(n=155)$ for girls. The values are shown in Table 2 .

For boys, the decrease in the frequency of self-control was related to the increase in sexual initiation and fights involvement. For girls, the increase in alcohol use, binge drinking, cannabis consumption and the feeling of loneliness were related to the reduction in the frequency of self-control.

The increased difficulty in self-control for boys was related to fights involvement. The girls who presented an increase in the difficulty of self-control had a relationship with the increase binge drinking, tobacco use and feeling of loneliness. Alcohol consumption was correlated with the increased difficulty in self-control for both genders. The results are shown in Tables 3 and 4.

Table 3. Bivariate analyzes of frequency in self-control, consumption indicators and risk factors in Brazilian adolescents, by gender, with chi-square. Foz do Iguaçu, Brazil, 2021.

\begin{tabular}{|c|c|c|c|c|c|c|}
\hline \multirow{4}{*}{ Variables } & \multicolumn{6}{|c|}{ Frequency } \\
\hline & \multicolumn{2}{|c|}{ Boys } & & \multicolumn{2}{|c|}{ Girls } & \multirow[b]{2}{*}{$P$} \\
\hline & Low & High & $p$ & Low & High & \\
\hline & \multicolumn{2}{|c|}{$\%(n)$} & & \multicolumn{2}{|c|}{$\%(\mathrm{n})$} & \\
\hline \multicolumn{7}{|l|}{ Alcohol use (in life) } \\
\hline Yes & $74.1(86)$ & $71.7(152)$ & & $80.1(133)$ & $71.5(163)$ & \\
\hline No & $25.9(30)$ & $28.3(60)$ & 0.636 & $19.9(33)$ & $28.5(65)$ & $0.050^{*}$ \\
\hline \multicolumn{7}{|c|}{ Alcohol consumption (last month) } \\
\hline Yes & $46.6(54)$ & $44.8(95)$ & & $44(73)$ & $38.2(87)$ & \\
\hline No & $53.4(62)$ & $55.2(117)$ & 0.762 & $56(93)$ & $61.8(141)$ & 0.246 \\
\hline \multicolumn{7}{|l|}{ Binge drinking (in life) } \\
\hline Yes & $44.8(52)$ & $37.3(79)$ & & $45.2(75)$ & $35.1(80)$ & \\
\hline No & $55.2(64)$ & $62.7(133)$ & 0.181 & $54.8(91)$ & $64.9(148)$ & $0.043 *$ \\
\hline \multicolumn{7}{|l|}{ Tobacco use (in life) } \\
\hline Yes & $35.3(41)$ & $34(72)$ & & $35.5(59)$ & $30.7(70)$ & \\
\hline No & $64.7(75)$ & $66(140)$ & 0.801 & $64.5(107)$ & $69.3(158)$ & 0.312 \\
\hline \multicolumn{7}{|c|}{ Cannabis consumption (last month) } \\
\hline Yes & $8.6(10)$ & $7.1(15)$ & & $5.4(9)$ & $1.8(4)$ & \\
\hline No & $91.4(106)$ & $92.9(197)$ & 0.614 & $94.6(157)$ & $98.2(224)$ & $0.044 *$ \\
\hline \multicolumn{7}{|c|}{ Feeling of loneliness (last year) } \\
\hline Never/ Rarely & $81(94)$ & $79.7(169)$ & & $65.1(108)$ & $77.2(176)$ & \\
\hline Always & $19(22)$ & $20.3(43)$ & 0.775 & $34.9(58)$ & $22.8(52)$ & $0.008^{*}$ \\
\hline \multicolumn{7}{|l|}{ Sexual initiation } \\
\hline Yes & $65.5(76)$ & $48.1(102)$ & & $46.4(77)$ & $45.6(104)$ & \\
\hline No & $34.5(40)$ & $51.9(110)$ & $0.002 *$ & $53.6(89)$ & $54.4(124)$ & 0.879 \\
\hline \multicolumn{7}{|c|}{ Fight Involvement (last year) } \\
\hline Yes & $28.4(33)$ & $17.5(37)$ & & $11.4(19)$ & $6.1(14)$ & \\
\hline No & $71.6(83)$ & $82.5(175)$ & $0.020 *$ & 88.6 (147) & $93.9(214)$ & 0.061 \\
\hline
\end{tabular}

Note: $p<0,05$

The results of the Binomial Logistic Regression analysis for the association between self-control, consumption indicators and risk factors in adolescents in border region were analyzed using two adjusted models, in which the regression explained $4 \%$ of the frequency variance (Hosmer and Lemeshow $\chi^{2}=20.806(10), \mathrm{p}=0.022$ Nagelkerke $\left.R^{2}=0.039\right)$ and $7 \%$ of the difficulty $\left(\chi^{2}=40.895\right.$ (10), $\mathrm{p}<0.001$ Nagelkerke $\left.R^{2}=0.075\right)$ of self-control for the model indicators. The condition of having a decrease in the frequency of self-control has a negative relationship with the variable fights involvement (fights involvement increases the chance of being in this group by 0.57 times).

The model also presents an increased difficulty in self-control with a positive relationship with the variable alcohol consumption (consuming alcohol increases the chance of being in this group by 0.60 
times) and the feeling of loneliness (the increase in the feeling of loneliness increases the chance of being in this group by 0.56 times. The results are shown in Table 5.

Table 4. Bivariate analyzes of the difficulty in self-control, consumption indicators and risk factors in Brazilian adolescents, by gender, with chi-square. Foz do Iguaçu, Brazil, 2021.

\begin{tabular}{|c|c|c|c|c|c|c|}
\hline \multirow{4}{*}{ Variables } & \multicolumn{6}{|c|}{ Difficulty } \\
\hline & \multicolumn{2}{|c|}{ Boys } & \multirow[b]{2}{*}{$p$} & \multicolumn{2}{|c|}{ Girls } & \multirow[b]{2}{*}{$p$} \\
\hline & Low & High & & Low & High & \\
\hline & \multicolumn{2}{|c|}{$\%(n)$} & & \multicolumn{2}{|c|}{$\%(n)$} & \\
\hline \multicolumn{7}{|l|}{ Alcohol use (in life) } \\
\hline Yes & $68.3(95)$ & $75.7(143)$ & & $70,9(90)$ & $77.2(206)$ & \\
\hline No & $31.7(44)$ & $24.3(46)$ & 0.142 & $29.1(37)$ & $22.8(61)$ & 0.177 \\
\hline \multicolumn{7}{|c|}{ Alcohol consumption (last month) } \\
\hline Yes & $36.7(51)$ & $51.9(98)$ & & $32.3(41)$ & $44.6(119)$ & \\
\hline No & $63.3(88)$ & $48.1(91)$ & $0.006^{*}$ & $67.7(86)$ & $55.4(148)$ & $0.020 *$ \\
\hline \multicolumn{7}{|l|}{ Binge drinking (in life) } \\
\hline Yes & $37.4(52)$ & $41.8(79)$ & & $29.9(38)$ & $43.8(117)$ & \\
\hline No & $62.6(87)$ & $58.2(110)$ & 0.423 & $70.1(89)$ & $56.2(150)$ & $0.008^{*}$ \\
\hline \multicolumn{7}{|l|}{ Tobacco use (in life) } \\
\hline Yes & $28.8(40)$ & $38.6(73)$ & & $26(33)$ & $36(96)$ & \\
\hline No & $71.2(99)$ & $61.4(116)$ & 0.064 & $74(94)$ & $64(171)$ & $0.049 *$ \\
\hline \multicolumn{7}{|c|}{ Cannabis consumption (last month) } \\
\hline Yes & $7.9(11)$ & $7.4(14)$ & & $0.8(1)$ & $4.5(12)$ & \\
\hline No & $92.1(128)$ & $92.6(175)$ & 0.864 & $99.2(126)$ & $95.5(255)$ & 0.054 \\
\hline \multicolumn{7}{|c|}{ Feeling of loneliness (last year) } \\
\hline Never/ Rarely & $84.9(118)$ & $76.7(145)$ & & $81.9(104)$ & $67.4(180)$ & \\
\hline Always & $15.1(21)$ & $23.3(44)$ & 0.067 & $18.1(23)$ & $32.6(87)$ & $0.003 *$ \\
\hline \multicolumn{7}{|l|}{ Sexual initiation } \\
\hline Yes & $49.6(69)$ & $57.7(109)$ & & $44.9(57)$ & $46.4(124)$ & \\
\hline No & $50.4(70)$ & $42.3(80)$ & 0.149 & $55.1(70)$ & $53.6(143)$ & 0.771 \\
\hline \multicolumn{7}{|c|}{ Fight Involvement (last year) } \\
\hline Yes & $15.1(21)$ & $25.9(49)$ & & $7.1(9)$ & $9(24)$ & \\
\hline No & 84.9 (118) & $74.1(140)$ & $0.018^{*}$ & $92.9(118)$ & $91(243)$ & 0.524 \\
\hline
\end{tabular}

Note: ${ }^{*} p<0.05$

Table 5. Relationship between frequency and difficulty in self-control, consumption indicators and risk factors in Brazilian adolescents, Binomial logistic regression. Foz do Iguaçu, Brazil, 2021.

\begin{tabular}{llrlr}
\multicolumn{1}{c}{ Variables } & \multicolumn{1}{c}{ Frequency } & \multicolumn{2}{c}{ Difficulty } & $p$ \\
\hline & Model $\chi^{2}=20.806$ & & Model $\chi^{2}=40.895$ & $<0.001^{*}$ \\
\hline Alcohol use (in life) & $0.85(0.56-1.32)$ & 0.484 & $1.06(0.70-1.61)$ & 0.787 \\
Alcohol consumption (last month) & $1.08(0.74-1.57)$ & 0.681 & $0.60(0.41-0.89)$ & $0.011^{*}$ \\
Binge drinking (in life) & $0.79(0.54-1.17)$ & 0.239 & $0.92(0.62-1.39)$ & 0.706 \\
Tobacco use (in life) & $1.13(0.79-1.61)$ & 0.517 & $0.78(0.53-1.13)$ & 0.192 \\
Cannabis consumption (last month) & $0.89(0.42-1.85)$ & 0.746 & $1.53(0.69-3.41)$ & 0.297 \\
Feeling of loneliness (last year) & $0.79(0.55-1.13)$ & 0.189 & $0.56(0.38-0.83)$ & $0.004^{*}$ \\
Sexual initiation & $0.81(0.57-1.13)$ & 0.211 & $0.90(0.64-1.28)$ & 0.561 \\
Feeling of loneliness (last year) & $0.57(0.36-0.91)$ & $0.017^{*}$ & $0.67(0.41-1.10)$ & 0.114 \\
\hline
\end{tabular}

Note: OR, odd ratio; The analyses were adjusted for age and sex; ${ }^{*} p<0.05$. 


\section{DISCUSSION}

The objective of this research was to analyze the association between self-control, consumption indicators and risk factors in adolescent's behaviour. The results obtained suggest that fight involvement, alcohol consumption and feeling of loneliness are associated with adolescent's selfcontrol. These results are confirmed by a previous study related to the influence of emotional selfcontrol on loneliness and substance use (Nikmanesh et al., 2015).

The greater vulnerability of boys in the consumption indicators and other risk factors in the adolescent's behaviour pointed out in this study, was a trend in population studies (Malta et al., 2018) demonstrating the increase in alcohol consumption among girls in recent years (Freitas et al., 2019) in border region (Priotto, 2019). These data are important for researchers and managers when planning future interventions.

The relationship between the frequency of self-control and risk factors in adolescents behaviour was also identified in the results of a long-term survey, that showed that the decrease in self-control in adolescence influences the maintenance of risk behaviours for sexuality in adulthood (Griffin et al., 2012). In the same direction, the variety of risk factors associated with reduced self-control identified in this study, represent the importance and complexity of setting priorities for interventions involving adolescent health prevention (Davies et al., 2017; Walters et al., 2018). Similar results were presented by studies that demonstrated low levels of self-control in adolescents in relation to multiple risk factors (de Winter et al., 2016), alcohol use (Bobrowski, 2019; Wills et al., 2016), binge drinking (Ismayilova \& Terlikbayeva, 2018), victimization by violence (Davis et al., 2017), tobacco use (Fauzan et al., 2018; Holmes, 2018) and alcohol use associated with premature sexual activity in adolescents (Agbaria et al, 2017).

In addition, this evidence highlights the importance of the fights involvement, alcohol consumption and feeling of loneliness in planning research and interventions with adolescents in border region, giving importance to learning self-control strategies related to substance use behaviours and other risk factors in adolescents. Therefore, from the point of view of health education in relation to health prevention and promotion, family, school and peer relationships are important and should be better explored as regulators of isolation reactions and other risk behaviours (De la Fuente et al., 2017). These results point out the importance of programs aimed at preventing consumption indicators, based on the training of self-control to manage behaviours of fight involvement, alcohol consumption and isolation.

The study presents a complex and rigorous sampling process, making it possible to generalize the results to the population, being useful for the use of health behavior monitoring. However, some limitations can be clarified, the study was self-reported and presents a cross-sectional design methodology, and it is not possible to establish a cause-effect relationship. The study also addressed the relationship between self-control and the survey indicators, thus not demonstrating the relationship between the other classes of social skills as well as the general repertoire.

The results of this study identified the association of self-control with consumption indicators and risk factors in adolescent's behaviour, mainly identifying self-control as a protective factor for the fight involvement, alcohol consumption and feeling of loneliness. This risk behaviours evaluated in the research reveal a priority for intervention in Brazilian adolescents for the development of future studies in border region. Thus, it is essential to plan research and interventions based on the promotion of self-control, in addition to carrying out interventions in conjunction with school, family and peers in order to reduce consumption indicators and other risk factors in adolescence.

The results call attention to the importance of studies of this nature for the design of more effective intervention programs and policies, in addition to the prioritization of results identified in population surveys to improve coping strategies in education and health. Finally, this study confirms the impact of consumption indicators and risk behaviours in adolescent's behavior and the importance of selfcontrol as a strategy for the development of education and public health programs and policies. 
Key points

1. Self-control in adolescents is associated with fight involvement, alcohol consumption and feeling of loneliness.

2. The factors alcohol use, binge drinking and cannabis consumption, feeling of loneliness and fight involvement are related to the low frequency of self-control for girls.

3. For boys, sexual initiation and fight involvement were related to the frequency of self-control.

4. Feeling of loneliness, alcohol consumption, binge drinking and cannabis consumption were related to increased difficulty in self-control for girls.

5. For boys, the increased difficulty in self-control was related to the alcohol consumption, feeling of loneliness and fight involvement.

Funding: This study was financed in part by the Coordenação de Aperfeiçoamento de Pessoal de Nível Superior - Brasil (CAPES) - Finance Code 001.

\section{REFERENCES}

Agbaria, Q., Berte, D. Z., \& Mahamid, F. A. (2017). Social Support, Self-Control, Religiousness and Engagement in High Risk-Behaviors among Adolescents. The International Journal of Indian Psychology, 4(October). https://doi.org/10.25215/0404.142

Bobrowski, K. J., Greń, J., Ostaszewski, K., \& Pisarska,. A. (2019). Factors related to the alcohol use among students attending youth correctional centres. Alcohol Drug Addict, 32(4), 317-336. https://doi.org/10.5114/ain.2019.94025.

Brasil. Ministério da Saúde. (2016). Pesquisa nacional de saúde do escolar : 2015. Instituto Brasileiro de Geografia e Estatística - IBGE.

Coutinho, E. S. F., Magliano, E. S., Bloch, K. V., Barufaldi, L. A., Cunha, C. F., De Vasconcellos, M. T. L., \& Szklo, M. (2016). ERICA: Patterns of alcohol consumption in Brazilian adolescents. Revista de Saúde Publica, 50(suppl 1), 1s-9s. https://doi.org/10.1590/S015188787.2016050006684

Davies, L. E. M., Kuipers, M. A. G., Junger, M., \& Kunst, A. E. (2017). The role of self-control and cognitive functioning in educational inequalities in adolescent smoking and binge drinking. $B M C$ Public Health, 17(1), 1-9. https://doi.org/10.1186/s12889-017-4753-2

Davis, J. P., Dumas, T. M., Berey, B. L., Merrin, G. J., Cimpian, J. R., \& Roberts, B. W. (2017). Effect of victimization on impulse control and binge drinking among serious juvenile offenders from adolescence to young adulthood. Journal of Youth and Adolescence, 46(7), 1515-1532. https://doi.org/10.1007/s10964-017-0676-6

De la Fuente, J., Cubero, I., Sánchez-Amate, M. C., Peralta, F. J., Garzón, A., \& Fiz Pérez, J. (2017). The adolescent's competency for interacting with alcohol as a determinant of intake: The role of self-regulation. Frontiers in Psychology, 8(oct), 1-14. https://doi.org/10.3389/fpsyg.2017.01800

Del Prette A., \& Del Prette Z. (2009). Inventário de Habilidades Sociais para Adolescentes (IHSADel-Prette): Manual de aplicação, apuração e interpretação. Casa do Psicólogo.

de Winter, A. F., Visser, L., Verhulst, F. C., Vollebergh, W. A. M., \& Reijneveld, S. A. (2016). Longitudinal patterns and predictors of multiple health risk behaviors among adolescents: The Trails study. Preventive Medicine, 84, 76-82. https://doi.org/10.1016/j.ypmed.2015.11.028

Dos Reis, A. A. C., Malta, D. C., \& Furtado, L. A. C. (2018). Challenges for public policies aimed at adolescence and youth based on the national scholar health survey (PeNSE). Ciencia e Saude Coletiva, 23(9), 2879-2890. https://doi.org/10.1590/1413-81232018239.14432018 
Fauzan, F., Firman, F., \& Daharnis, D. (2018). Relationship between self-control and peer conformity with smoking behavior. International Conferences on Educational, Social Sciences and Technology. https://doi.org/10.29210/2018134

Freitas, E. A. D. O., Martins, M. S. A. S., \& Espinosa, M. M. (2019). Alcohol and tobacco experimentation among adolescents of the midwest region/Brazil. Ciencia e Saúde Coletiva, 24(4), 1347-1357. https://doi.org/10.1590/1413-81232018244.15582017

Griffin, K. W., Scheier, L. M., Acevedo, B., Grenard, J. L., \& Botvin, G. J. (2012). Long-term effects of self-control on alcohol use and sexual behavior among urban minority young women. International Journal of Environmental Research and Public Health, 9(1), 1-23. https://doi.org/10.3390/ijerph9010001

Hallal, A. L. de L. C., Figueiredo, V. C., Moura, L. de, Prado, R. R. do, \& Malta, D. C. (2017). Uso de outros produtos do tabaco entre escolares brasileiros (Pense 2012). Cadernos de Saúde Publica, 33, 174-183. https://doi.org/10.1590/0102-311X00137215

Holmes, C. J. (2018). Today's decisions, Tomorrow's outcomes: Does self-control explain the educational smoking gradient? Social Science Research, 70(October 2016), 229-241. https://doi.org/10.1016/j.ssresearch.2017.10.009

Horta, R. L., De Mola, C. L., Horta, B. L., De Mattos, C. N. B., De Andreazzi, M. A. R., OliveiraCampos, M., \& Malta, D. C. (2018). Prevalence and factors associated with illicit drug use throughout life: National School Health Survey 2015. Revista Brasileira de Epidemiologia, (21) (Suppl 1). https://doi.org/10.1590/1980-549720180007.supl.1

Ismayilova, L., \& Terlikbayeva, A. (2018). Building Competencies to Prevent Youth Substance Use in Kazakhstan: Mixed Methods Findings From a Pilot Family-Focused Multimedia Trial. Journal of Adolescent Health, 63(3), 301-312.

Kim, Y. K., Okumu, M., Small, E., Nikolova, S. P., \& Mengo, C. (2018). The association between school bullying victimization and substance use among adolescents in Malawi: The mediating effect of loneliness. International Journal of Adolescent Medicine and Health, 1-9. https://doi.org/10.1515/ijamh-2017-0229

Malta, D. C., Machado, Í. E., Felisbino-Mendes, M. S., Prado, R. R. Do, Pinto, A. M. S., OliveiraCampos, M., De Souza, M. D. F. M., \& Assunção, A. A. (2018). Use of psychoactive substances among Brazilian adolescents and associated factors: National School-based Health Survey, 2015. Revista Brasileira de Epidemiologia, 21(Suppl 1). https://doi.org/10.1590/1980549720180004.supl.1

Matos, M., \& Equipa Aventura Social. (2018). A saúde dos adolescentes portugueses após a recessão. Health Behaviour in School - Aged Children, 62.

Oliveira, M. M. de, Campos, M. O., Andreazzi, M. A. R. de, \& Malta, D. C. (2017). Características da Pesquisa Nacional de Saúde do Escolar - PeNSE. Epidemiologia e Servicos de Saude, 26(3), 605-616. https://doi.org/10.5123/S1679-49742017000300017

Walters, K. J., Simons, J. S., \& Simons, R. M. (2018). Self-control demands and alcohol-related problems: Within- and between-person associations. Psychology of Addictive Behaviors, 32(6), 573-582.

WHO. (2016). Growing up unequal: gender and socioeconomic differences in young people 's health and well-being. WHO Regional Office for Europe.

Wills, T. A., Simons, J. S., Sussman, S., \& Knight, R. (2016). Emotional self-control and dysregulation: A dual-process analysis of pathways to externalizing/internalizing symptomatology and positive well-being in younger adolescents. Drug and Alcohol Dependence, 163, 37-45. https://doi.org/10.1016/j.drugalcdep.2015.08.039

Nikmanesh, A., Kazemi, Y., \& Khosravi, M (2015). Role of Feeling of Loneliness and Emotion Regulation Difficulty on Drug Abuse. Journal of Community Health Research, 4(1), 55-64. 